\title{
The Influence of Personality Characteristics on Individual Competencies of Work Group Members: A Cross-cultural Study
}

\author{
Georg Kodydek 1 , Ronald Hochreiter ${ }^{2}$ \\ ${ }^{1}$ WU Vienna University of Economics and Business, Department of Management, Institute for Change Management and \\ Management Development, Welthandelsplatz 1, 1020 Vienna, Austria, georg.kodydek@wu.ac.at \\ ${ }^{2}$ WU Vienna University of Economics and Business, Department of Finance, Accounting \& Statistics, Institute for Statistics \\ and Mathematics, Welthandelsplatz 1, 1020 Vienna, Austria, ronald.hochreiter@wu.ac.at
}

\begin{abstract}
In this article, we investigate how college students and graduates with diverse backgrounds experience working in groups by focusing on their perceptions regarding group work, attribution of leader coaching, and self-perspectives of personality traits. Moreover, this article explores relationships between personality factors (using the Big Five factors) and selected individual competencies from Bartram's Great Eight Competencies (2005). We furthermore review current management research on competency management, personality, and also identify current trends for young professionals who are about to enter the job market. This study was conducted in an experimental setting at a large European business school. Participants were 80 business students from Austria, Turkey, China, and the United States of America with a fairly even gender split who had to work on tasks in homogeneous and heterogeneous settings. We assess participants' ratings following Rammstedt and John's Big Five Inventory (2007) and a modified version of Wageman, Hackman and Lehman's Team Diagnostic Survey (2005) that we enhanced accordingly. Results are analyzed and discussed with relation to global challenges and developments regarding competencies, diversity, and group work.
\end{abstract}

Key words: competency management, personality factors, individual competencies

\section{Introduction}

Today, companies face a competitive globally aligned environment with tremendous opportunities and serious challenges at the same time. Thus, organizations have to adapt quickly in order to compete effectively and achieve sustainable growth in multinational industries to remain successful on the market (Knight and Cavusgil, 2004). By focusing on an international perspective, companies desperately need the abilities, skills and expertise of talented employees who represent a major source of their competitive advantage (Hartmann, Feisl and Schober, 2010). Underlying this fact is the rapidly changing business environment and the growing aware of employees with multi-functional fluency, exceptional skills and knowledge, and the ability to operate in different cultures, structures and markets (Mühlbacher, Kodydek, Kovac, Putnová and
Novotny, 2012). The globalization has not only changed the challenges for organizations, it has also changed the duties and responsibilities of people. Leaders "must effectively manage through the complex, changing, and often ambiguous environment." (Caligiuri, 2006, 219). At the same time, followers have to work effectively in diverse work groups and teams that consist of people with multiple characteristics and backgrounds (Egan and Bendick Jr., 2008). Therefore, employees have to develop competencies to meet the requirements and needs of their firms (Currie, 2007).

\section{Competency Management}

There are several definitions of competencies that vary broadly based to very detailed (Sánchez, 2011). We identify competencies as capabilities that consist of skills, knowledge, abilities, and behavioral repertoires to perform specific jobs 
effectively and to complete tasks successfully (Bücker and Poutsma, 2010). "It is a set of related but different sets of behavior organized around an underlying construct called the 'intent'. The behaviors are alternate manifestations of the intent, as appropriate in various situations and times." (Boyatzis, 2009, 750). This field of research comprises from strategic to organizational to individual competencies (Mühlbacher 2007; Ferencikova, Mühlbacher, Kodydek and Nettekoven, 2012). While some scholars focused on the identification and development of different competencies in the past years, now most researchers have concentrated on investigating, analyzing, and managing one's emotions and influencing others (Kayes, Kayes and Yamazaki, 2005).

\section{Personality}

Organizations focus on selecting professionals with diverse backgrounds and a set of competencies to deal with challenges and issues of a competitive environment (Jehn and Bezrukova, 2004). As a result, several scholars have highlighted the relevance of personality measures for personnel selection (Salgado, 2003; Strauss and Connerley, 2003; Boudreau, Boswell and Judge, 2001). Personality can be defined as "an individual's unique variation on the general evolutionary design for human nature, expressed as a developing pattern of dispositional traits, characteristic adaptions, and integrative life stories complexly and differentially situated in culture." (McAdams and Pals, 2006, 212) Personality characteristics enable organizations to predict the level or quality of an individual's competencies and to obtain valuable information about the cognitive social ability of a person (Robertson, Gibbons, Baron, MacIver and Nyfield, 1999). On the basis of decades of factor analytic research (Hogan and Holland, 2003), scholars have identified five key traits regarding personality, commonly known as "Big Five": agreeableness (e.g., tolerant, forgiving, flexible, cooperative), conscientiousness (e.g., organized, thorough, responsible, hardworking), extraversion (e.g., active, sociable, talkative, assertive), openness (e.g., tolerant, imaginative, curious, broad-minded), and neuroticism or emotional stability (e.g., insecure, anxious, depressed, worried) (Strauss and Connerley, 2003; Boudreau, Boswell and Judge, 2001; for general reviews, see Goldberg, 1993). This model describes relevant aspects of personality and it has been used in longitudinal and in different groups across cultures (Mount, Barrick, Scullen and Rounds, 2005). Also, some researchers have pointed out that between selfand others' perspectives of an individual's personality characteristics could lead to different results and interpretations (Srivastava, Guglielmo and Beer, 2010).

\section{Challenges for college students and graduates}

What about college students and graduates who are about to enter the job market? They constitute future highly trained and skilled professionals (Hoon and Lim, 2001) and moreover, some of them are the next generation of business leaders and decision-makers (Bageac et al., 2011). Students and graduates have already developed strong work values based on their personal values, experiences and perceptions of what is fundamentally right or wrong (Judge and Bretz Jr., 1992).
These young professionals face two important trends in a globalized world: an increased preference for group work and a growing influence of diversity and diversity management (Sippola and Smale, 2007). One of the most important reasons for groups and teams is the fact that every member possesses certain competencies - skills, and abilities - that influence processes, quality and outcome of groups (Horwitz, 2005). Individuals as group members interact within a group by communicating, influencing, making decisions, cooperating, and competing. All these processes influence group performance and group dynamics (Hopkins and Hopkins, 2002). Groups and teams share responsibilities, communicate and interact regularly among one another and manage their internal and external relationships across organizational boundaries (Cohen and Bailey, 1997). In comparison with individual work, group processes can lead to greater efficiency (e.g., increasing speed in decision-making, effective brainstorming processes, reducing costs) or greater effectiveness (e.g., making better decisions). It usually increases productivity, outcomes and employee satisfaction (Campion, Medsker and Higgs, 1993). To understand possible differences in group composition it is important to define and emphasize the second trend that we identified: "diversity".

Diversity can be illustrated as the differences between individuals that may lead to the interpretation and attribution that certain differences exist (Homan, Greer, Jehn and Koning, 2010). It is an all-inclusive term that incorporates people from many different classifications (Herring, 2009). We underline that, in principle, diversity refers to a number of different dimensions - from task skills to relational skills, and from political preferences to sexual liking (van Knippenberg, De Dreu and Homan, 2004). In any case, diversity is dependent on the context and situation and thus, group and organizational factors have to be considered (Jehn and Bezrukova, 2004). Cultural diversity comprises different backgrounds of members of work groups and teams related to national cultures (Barinaga, 2007). "National culture acts as the frame of reference, which societal members utilize to comprehend and understand in organizations, the environment, and their relationships with one another." (Kreiser, Marino, Dickson and Weaver, 2010, 961). The active management and handling with issues such as cultural differences and values, interpersonal interaction, bridging differences, or the challenges of leader-member exchange is called "diversity management" (DiTomaso and Hooijberg, 1996). "Diverse organizations possess a wider range of knowledge and perspectives and thus are able to make better decisions and exhibit greater creativity, innovation, and performance than homogeneous ones." (Gonzalez, 2010, 198). Organizations focus on implementing diversity management to follow strategic advantages of plurality and different views and opinions (Jehn, Northcraft and Neale, 1999). The heterogeneity of national cultures of team members ultimately brings value to organizations and improves their performance when cultural diversity is properly used (Shachaf, 2008). For this reasons, globally operating firms try to find the best internationally oriented and multiculturally educated staff that generates a substantial output to cope with challenges and complexities of global competitors, different cultures and languages and international business 
activities (Beechler and Woodward, 2009). Diversity can have positive and negative effects on group cohesion, creativity, innovation, frequency and quantity of communication, or conflicts within the group (Knight, Pearce, Smith, Olian, Sims, Smith and Flood, 1999).

In this paper, we focus on two different group compositions - homogeneous and heterogeneous work groups. "Groups with all members from the same nationality and ethnic background are referred to herein as culturally homogeneous groups." (Watson, Kumar and Michaelsen, 1993, 593). Otherwise, groups consisting of individuals from two or more nationalities and three or more ethnic backgrounds underline certain heterogeneity and are known as culturally diverse groups or multicultural groups (Stahl, Mäkelä, Zander and Maznevski, 2010). Multicultural work groups are taskoriented groups consisting of individuals of different national cultures (Matveev and Nelson, 2004). "People of different ethnic backgrounds possess different attitudes, values, and norms that reflect their cultural heritages." (Cox, Lobel and McLeod, 1991, 828). Thus, in a culturally diverse team, all team members have to know the cultures with which they interact. They also have to appreciate the personalities, behaviors, and experiences of all team members (Matveev and Nelson, 2004). Hence, we emphasize the importance of intercultural competency as an important part of "global competency" which has been pointed out many times (e.g., Bachmann, 2006; Kayes, Kayes and Yamazaki, 2005).

In summary, young professionals have to take responsibility for difficult (global) tasks and activities, and develop cultural sensitivity for international challenges. Furthermore, they have to work in multicultural work groups or teams, persist in diverse environments and develop their intercultural competencies continuously. Therefore, they have to speak several languages and need to be able to adapt to multicultural challenges appropriately (Welch, Welch, and Piekkari, 2005).

\section{Purpose of our study}

In our study, we focused on college students and graduates who are about to enter the job market in the near future. In order to investigate the two identified trends for future professionals, we therefore concentrated empirically on different work groups with participants from Austria, Turkey, China, and the United States of America. We therefore analyzed perceptions of students concerning their group work, their attributions of leader coaching, and their self-perspectives of personality characteristics during a task in an experimental setting.

\section{Development of Hypotheses}

Many researchers have investigated the relationship between competencies and personality traits over the last years (e.g. Bartram, 2005; Dulewicz and Herbert, 1999; Robertson, Gibbons, Baron, MacIver and Nyfield, 1999). Bartram (2005) illustrated a competency framework that consists of the Great Eight Competencies, 20 competency dimensions and 112 competency component titles (for more details, see Bartram, 2005). The Great Eight Competency structure refers to a wide range of models used by practitioners in competency practice. It is also supported empirically and is similar to common competency clusters in this research field (Bartram, 2005). The eight identifiable categories are "Leading and Deciding", "Supporting and Cooperating", "Interacting and Presenting", "Analyzing and Interpreting", "Creating and Conceptualizing", "Organizing and Executing", "Adapting and Coping" and "Enterprising and Performing". In order to explore relationships between competencies and personality factors of students and graduates through an experiment, we focus on Bartram's suggestion of relationships and therefore concentrate on the competencies "Supporting and Cooperating" and "Organizing and Executing" (Warr, Bartram and Brown, 2005). In our opinion, these competencies seem most relevant regarding our research context. The competency "Supporting and Cooperating" illustrates the support and respect of others, the effective work with individuals and groups, and the strong relation between personal and organizational values (Bartram, 2005). Bartram (2005) predicted a relationship between this competency and agreeableness which constitutes the personality characteristic of being tolerant, caring, and gentle (Strauss and Connerley, 2003; Boudreau, Boswell and Judge, 2001). "Organizing and Executing", on the other hand, represents the planning and working in systematic and organized ways, the following of directions and procedures, the focus on customer satisfaction and the delivery of outstanding quality and standards (Bartram, 2005). Bartram (2005) predicted here a relationship between this competency and conscientiousness which illustrates an individual who is hardworking, thorough, and organized (Strauss and Connerley, 2003; Boudreau, Boswell and Judge, 2001). Furthermore, Hogan and Ones (1997) argued that this personality trait is the major component of integrity. In this paper, we focus on the individual's perspective which refers to the dynamics and processes inside a person. Moreover, it explains why individuals behave in a certain way (Mount, Barrick and Strauss, 1994). Thus, we propose the following hypothesis:

Hypothesis 1a: Regarding the competency "Supporting and Cooperating”, agreeableness will be positively related to compelling direction.

Hypothesis 1b: Regarding the competency "Organizing and Executing", conscientiousness will be positively related to leader coaching.

A certain level of group information process leads to a better understanding of the task setting (Rico, SánchezManzanares, Gil and Gibson, 2008). Compelling direction refers to the direction of a work group and its overall purpose (Hackman and Wageman, 2005). Great group direction is "challenging (which energizes members), clear (which orients them to their main purposes), and consequential (which engages the full range of their talents)." (Wageman, Hackman and Lehman, 2005, 377). An ensured compelling direction energizes and motivates group members. Moreover, goals are opportunities for personal growth (Burke, Sims, Lazzara and Salas, 2007). In addition, group work is generally influenced by leaders who create and manage groups and foster the integration of subordinate action (Zaccaro, Rittman and Marks, 2001). Researchers in this field have explored how leaders help groups through different coaching-related activi- 
ties, such as promoting team learning and adaption, managing events that occur in the group context, the role of team leaders in managing team boundaries, or leadership roles shared in teams (Morgeson, DeRue and Karam, 2010). It includes helping group members minimizing motivation and coordination problems, building commitment, avoiding standard routines that could lead to a wrong direction, supporting the group to apply innovative ways to reach their goals. Furthermore, coaching also comprises helping group members to weight certain ideas, and to help them improve their skills (Burke, Sims, Lazzara and Salas, 2007; Hackman and Wageman, 2005). Leader coaching "can directly affect team members' engagement with their task, their ability to work through interpersonal problems that may be impeding process, and the degree to which members accept collective responsibility for performance outcomes." (Wageman, 2001, 561). In any case, whether it is a diverse or a homogeneous work group - working in different group settings is often a challenge for many individuals (Pelled, Eisenhardt and Xin, 1999). Hence, proactive leadership and coaching could affect group processes and outcomes substantially (Wageman, 2001). We therefore hypothesize the following:

Hypothesis 2a: Participants who rate positively on clarity, challenge, and consequentiality after the first round will not rate their own personality differently after the second round of the experiment than will participants who rate negatively on clarity, challenge, and consequentiality.

Hypothesis 2b: Participants who rate positively on leader coaching after the first round will not rate their own personality differently after the second round of the experiment than will participants who rate negatively on clarity, challenge, and consequentiality.

Scholars have demonstrated that diversity ultimately enables organizations to gain competitive advantage (Richard, Barnett, Dwyer and Chadwick, 2004; Richard, 2000). As mentioned earlier, it mostly extends organizational perspectives, capabilities and offers outstanding opportunities, but also challenges organizations and its members (Harrison and Klein, 2007). Ely and Thomas (2001) illustrated that the wide impact of diversity generally can be found in identity group memberships (e.g., race or sex), organizational group memberships (e.g., hierarchical positions or organizational function), and individual personality (e.g., idiosyncratic attitudes, values, and preferences). An individual's personality consists of certain characteristics, traits, behaviors, and experiences situated in his or her culture (McAdams and Pals, 2006). The influence of national culture and ethnic background on individuals' perceptions, attributions, expectations of group work, tasks, and leadership, and self-perspectives of personality characteristics has been underlined by many researchers (e.g., Zhou and Shi, 2011; Tyran and Gibson, 2008; Hackman and Wageman, 2005). Regarding gender differences across cultures, scholars have also investigated this research field intensively and they have demonstrated different findings due to various influencing factors, such as situational effects and hierarchical position (Brummett, Babyak, Williams, Barefoot,
Costa and Siegler, 2006; Furnham, Petrides, Tsaousis, Pappas and Garrod, 2005). Thus, we predict:

Hypothesis 3a: Austrian male participants will rate their own personality more consistently throughout the experiments than Austrian female participants.

Hypothesis 3b: Turkish male participants will rate their own personality more consistently throughout the experiments than Turkish female participants.

Hypothesis 3c: Chinese male participants will rate their own personality more consistently throughout the experiments than Chinese female participants.

Hypothesis 3d: US-American male participants will rate their own personality more consistently throughout the experiments than US-American female participants.

Hypothesis 4: There is a significant difference between Austrian, Turkish, Chinese and US American students regarding the attribution of compelling direction and leader coaching in the experiment.

\section{Methodology}

Sample and Procedure

Participants were 80 undergraduate students from four nations (Austria, Turkey, China, and USA) at large European Business School. Eight work groups consisted of 72 participants while eight students were selected as leaders in this experiment $(N=$ 72,33 male and 39 female; mean age $=22.57$ years). All participants were full-time or exchange students at this university at the time of the experiment and could speak English fluently. We only included male leaders to eliminate gender effects.

At the beginning of the study we divided the participating students into eight homogeneous work groups and selected eight leaders for the task that took two rounds. Every participating nation (Austria, Turkey, China, and USA) was represented by two leaders and an identical number of followers for every group. The subordinates had to work in a homogeneous and heterogeneous work group. In order to prevent learning effects, we decided to compose groups differently (e.g., in the first round "American leader A" led a homogeneous team while "American leader B" led a multicultural team). In the second round the leaders remained stable but the followers had to move to a predefined specified group. The experiments took place in different rooms and were observed by experienced instructors. The task was handed over by these people. The assignment was to design and build a tower made of cardboard and predefined tools within 30 minutes. The leadership style and the working process were not specified by the instructors. After 30 minutes the leaders of the work group handed over the output of the group to the observer. The followers adjourned themselves to another specified room and worked on the task within another group. After every round the participants were asked to complete a questionnaire asking them to rank their self-perspectives of personality characteristics, their own personal view of their group performance, the task, and the leader coaching.

Measures

We administered questionnaires in English and pilot tested the survey instrument that was developed from differ- 
Table 1: Descriptive statistics and correlations

\begin{tabular}{|l|c|c|c|c|c|}
\hline & M & SD & Agreeableness & Conscientiousness & Compelling Direction \\
\hline Agreeableness & 3,42 & 0,65 & 1 & & \\
\hline Conscientiousness & 3,32 & 0,72 & 0.061 & & \\
\hline Compelling Direction & 3,05 & 0,5 & 0.158 & -0.045 & \\
\hline Leader Coaching & 2,95 & 0,78 & -0.008 & 0.108 & 0.045 \\
\hline
\end{tabular}

ent sources. It consisted of 30 items, some demographic and screening items (e.g.; major field of study). We employed the Big Five Inventory (BFI-10; Rammstedt and John, 2007; 10 items). This extremely short personality instrument enables surveys within a short period of time. Many short versions of the Big Five have indicated respectable psychometric characteristics, and underline the importance of short instruments (Rammstedt and John, 2007; Gosling, Rentfrow and Swann Jr., 2003). Furthermore, we used two scales from the Team Diagnostic Survey - an instrument intended for the diagnosis of the strengths and weaknesses of groups and for research on group behavior and performance (TDS; Wageman, Hackman and Lehman, 2005; 20 items). The TDS has been used in numerous studies and was shown to be an ideal instrument to assess group or team members' perceptions of the group's socio-structural features, such as compelling direction or enabling structure (Higgins, Weiner and Young, 2012; Hackman and Lehman, 2005). We adapted the TDS for our experiment and research context.

Big Five Personality Traits. The Big Five traits were measured with the short form of the Big Five Inventory (BFI-10; Rammstedt and John, 2007). The BFI-10 generally concentrates on the personal assessments and ratings of the participants to explore possible differences of the multicultural group members in an intercultural setting. The BFI10 measures every dimension (Extraversion, Agreeableness, Conscientiousness, Emotional Stability or Neuroticism, and Openness) with a pair of items (one is reverse coded). For example, extraversion $(1,6)$ is measured with the items "I see myself as someone who is outgoing, sociable" and "I see myself as someone who is reserved" (reverse coded). Ratings were made on a five-point scale ranging from 1 (disagree strongly) to 5 (agree strongly).

Compelling Direction. In this study, we measured "clarity", "challenge" and "consequentiality" using the Team Diagnostic six-item Scale "compelling direction" (Wageman, Hackman and Lehman, 2005). Thereby, we adapted this scale for our research context. A sample item from this scale was: "There is great uncertainty and ambiguity about what this work group is supposed to accomplish". Items were rated on a five-point scale, ranging from "disagree strongly" (response score $=1$ ) to "agree strongly" (response score $=5$ ).

Leader Coaching. We also measured direct interactions between followers and leaders that usually intend to shape group processes to produce good performance (Wageman, 2001) by using the Team Diagnostic 14-item Scale "leader coaching" (Wageman, Hackman and Lehman, 2005). We investigated "task focused coaching", "operant coaching", "interpersonal coaching" and "unhelpful directives". Thereby, group members rated their perceptions of their leaders' coaching on a five-point scale, ranging again from 1 (disagree strongly) to 5 (agree strongly). A Sample item was: "The leader helps the work group sustain the motivation of all members".

\section{Results}

Table 1 shows the means, standard deviations, and correlations of the study variables. This correlation was used to answer our first hypotheses: "Regarding the competency 'Supporting and Cooperating', agreeableness will be positively related to compelling direction" (H1a) and

"Regarding the competency 'Organizing and Executing', conscientiousness will be positively related to leader coaching" (H1b). Results suggested support for hypothesis 1a ( $\mathrm{r}$ $=0.158)$ and hypothesis $1 \mathrm{~b}(\mathrm{r}=0.108)$, and therefore, both hypothesis were confirmed.

Moreover, we hypothesized that participants who rate positively on clarity, challenge, and consequentiality after the first round of the experiment will not rate their own personality differently after the second round compared to students who rate negatively on clarity, challenge, and consequentiality (H2a). This hypothesis showed marginal support but within an acceptable region within the 90-percent confidence interval $(\mathrm{t}$ $=-1.7113, \mathrm{df}=67.814, \mathrm{p}=0.09159)$. Hypothesis $2 \mathrm{~b}$ predicted that participants who rate positively on leader coaching after the first round of the experiment will not rate their own personality differently after the second round of the experiment compared to participants who rate negatively on items of compelling direction. We could not find an empirical evidence for this hypothesis and hence, hypothesis $2 \mathrm{~b}$ was not supported $(\mathrm{t}$ $=1.0516, \mathrm{df}=68.539, \mathrm{p}=0.2967)$.

We then ran t-Tests to better understand differences among the participants of the experiment regarding gender and culture. As pointed out earlier, participants came from Austria, Turkey, China, and the US. Hypotheses 3a-d predicted that male participants will rate their own personality more consistently throughout the tasks than female students. However, findings showed no support for our hypotheses (Austrian students: $p=0.853$; Turkish students: $p=0.578$; Chinese students: $p=0.615$; US American students $=0.246$ ). For this reason, hypotheses 3a-d were rejected.

In our final prediction, we suggested that there is a significant difference between Austrian, Turkish, Chinese and US American participants regarding the attribution of compelling direction and leader coaching. We therefore ran an analysis of 
Table 2: Results of ANOVA

\begin{tabular}{|l|c|c|c|c|c|c|c|c|c|c|}
\hline & $\begin{array}{c}\text { M } \\
\text { AUT }\end{array}$ & $\begin{array}{c}\text { SD } \\
\text { AUT }\end{array}$ & $\begin{array}{c}\text { M } \\
\text { TUR }\end{array}$ & $\begin{array}{c}\text { SD } \\
\text { TUR }\end{array}$ & $\begin{array}{c}\text { M } \\
\text { CHN }\end{array}$ & $\begin{array}{c}\text { SD } \\
\text { CHN }\end{array}$ & $\begin{array}{c}\text { M } \\
\text { USA }\end{array}$ & $\begin{array}{c}\text { SD } \\
\text { USA }\end{array}$ & p & \\
\hline COMPELLING DIRECTION & & & & & & & & & & \\
\hline Clarity & 3,21 & 0,98 & 3,50 & 0,86 & 2,97 & 0,63 & 2,94 & 0,66 & 0,030 & $*$ \\
\hline Challenge & 2,74 & 0,60 & 3,17 & 0,61 & 3,10 & 0,58 & 3,00 & 0,70 & 0,130 & \\
\hline Consequentiality & 2,85 & 0,81 & 3,12 & 0,82 & 3,14 & 0,59 & 2,88 & 0,45 & 0,852 & \\
\hline LEADER COACHING & & & & & & & & & & \\
\hline Task Focused Coaching & 2,79 & 0,91 & 3,35 & 0,97 & 2,98 & 0,74 & 3,49 & 0,76 & 0,009 & $* *$ \\
\hline Operant Coaching & 2,47 & 0,79 & 3,04 & 0,80 & 2,76 & 0,67 & 2,87 & 0,66 & 0,103 & \\
\hline Interpersonal Coaching & 2,64 & 0,95 & 3,03 & 1,03 & 2,67 & 0,79 & 3,08 & 0,94 & 0,169 & \\
\hline Unhelpful Directives & 2,57 & 1,04 & 3,13 & 1,00 & 2,69 & 0,75 & 2,79 & 0,77 & 0,766 & \\
\hline Note: $* * * p<0.001,{ }^{* *} p<0.01,{ }^{*} p<0.05$ &
\end{tabular}

variance (ANOVA) to examine country differences on scores for the scales compelling direction and leader coaching.

The ANOVA showed that there was a significant difference between the four groups regarding Clarity $(p=0.030)$ and Task Focused Coaching $(\mathrm{p}=0.009)$. Turkish students denoted the highest evaluations in terms of clarity (arithmetic mean $=3.50$ ) whereas US participants indicated the lowest assessments (arithmetic mean $=2.94$ ). Regarding Task Focused Coaching, US American students indicated the highest ratings (arithmetic mean $=3.49$ ) whereas Austrian participants showed the lowest assessments (arithmetic mean $=2.79$ ). Thus, hypothesis 4 was partly supported.

\section{Discussion and Conclusion}

In this study, we sought to examine the influence of personality characteristics (agreeableness and conscientiousness) on individual competencies ("Supporting and Cooperating" and "Organizing and Executing") of students working in groups in an experiment. Moreover, we investigated if gender and cultural differences existed. Thus, we could identify positive relations between the personality trait "Agreeableness" and the direction of a work group and its overall purpose ("compelling direction") and also between "Conscientiousness" and coaching-related leader activities ("leader coaching") (H1a and $\mathrm{H} 1 \mathrm{~b}$ ). We gained empirical evidence that students with personal characteristics such as being tolerant, caring, and gentle, were motivated to achieve their goals (agreeableness), had a clear vision what has to be done, focused on the main purpose, and used their abilities and skills to fulfill the task successfully (Strauss and Connerley, 2003; Boudreau, Boswell and Judge, 2001). They developed competencies that can be related to "Supporting and Cooperating" (Bartram, 2005). These students respected their group members and were able to motivate others to participate actively and effectively throughout the tasks (Burke, Sims, Lazzara and Salas, 2007; Hackman and Wageman, 2005). Our findings also showed that participants with personal characteristics like hardworking, accepting responsibilities, and being organized (Strauss and
Connerley, 2003; Boudreau, Boswell and Judge, 2001), had a clear plan to fulfill the task, and most notably focused on following their leaders' directions and procedures to achieve high levels of performance and to attain goals (Burke, Sims, Lazzara and Salas, 2007; Hackman and Wageman, 2005). We emphasize that they developed competencies than can be related to "Organizing and Executing" (Bartram, 2005). Furthermore, they also tried to deliver excellent quality of work and to behave with integrity (Hogan and Ones, 1997).

Hypothesis $2 \mathrm{a}$ predicted that participants who rated positively on compelling direction after the first round of the experiment would not rate their own personality differently after the second round compared to students who rated negatively on clarity, challenge, and consequentiality. We found marginal support for this hypothesis. No empirical evidence could be found for hypothesis $2 b$ that predicted that students who rated positively on leader coaching after the first round of the experiment would not rate their own personality differently after the second round of the experiment. We argue that many participants did not have any intercultural experience, did not perform under pressure or were not led by a leader within a certain time period prior to the experiment. Many of them were obviously overwhelmed by their own impressions and experiences and therefore, rated their own personality differently after the two rounds (Moberg, 2006; Osland and Bird, 2000). Examinations of gender differences within national cultures regarding self-perspectives of personality characteristics (H3a-d) did not show significant differences between male and female participants.

We then investigated cross-cultural differences of perceptions and evaluations regarding compelling direction and leader coaching across the participants. The results indicated significant disparities of clarity and Task Focused Coaching. Although all groups had to work on identical tasks under the same conditions, we identified significant differences regarding the clarity of direction. Hackman and Wageman (2005) pointed out that in work groups, the clarity is sometimes unclear or vague. On the other hand, directions and statements can also be too clear. Findings also illustrated significant differences between the groups regarding Task Focused 
Coaching. This proactive coaching refers to leadership activities that support group effort, performance strategies, the use of skills and ideas, respectively (Wageman, Hackman and Lehman, 2005). Individuals generally develop a certain leadership style that is influenced by personal characteristics, experiences, training, situational factors, and ingrained behavior (Kolb and Kolb, 2005; Conger, 2004). In our study, we only included full-time students from four different countries with little or no work experience. However, even little practical experience offers valuable perceptions and ideas about work processes, leadership, and group work. Regarding our cross-cultural experiment, we also emphasize that some participants had more knowledge about cultural differences and were more satisfied with the outcome, the direction, the group performance, and their leaders in this experiment than others.

In this paper, we determined two challenges for college students and graduates: an increased preference for group work and a growing influence of diversity and diversity management. Young people therefore need to gain work experience through internships and practical training. Furthermore, as future professionals or even business leaders and decisionmakers, they need to develop specific competencies to be prepared for future challenges. Hence, they need to work on their so-called "career competencies" to get a fulfilling job and, moreover, to build a successful career in a globalized, competitive world (Vance, 2005). Career competencies are a higher-order learning process that includes capacity reflection, motivation reflection, work exploration, career directedness, and networking (Kuijpers, Meijers and Gundy, 2011). At the same time, they also need to concentrate on global competencies (Bücker and Poutsma, 2010). These training and development interventions can be divided into three broad categories: didactic learning programs, experiential opportunities, and intensive experiences (Caligiuri, 2006). Students and graduates should therefore focus on these strategies to obtain relevant competencies, skills, and awareness in order to overcome complex global assignments and challenges (Harvey and Novicevic, 2002). Finally, our findings could provide a valuable reference for academics to do further investigations on relevant issues.

\section{References}

Bachmann, A.S. (2006). Melting pot or tossed salad? Implications for designing effective multicultural workgroups. Management International Review, 46(6), 721-747, http://dx.doi.org/10.1007/ s11575-006-0124-4

Bageac, D., Furrer, O. \& Reynaud, E. (2011). Management students' attitudes toward business ethics: A comparison between France and Romania. Journal of Business Ethics, 98 (3), 391-406, http://dx.doi.org/10.1007/s10551-010-0555-5

Barinaga, E. (2007). 'Cultural diversity' at work: 'National culture' as a discourse organizing an international project group. Human Relations, 60(2), 315-340, http://dx.doi. org/10.1177/0018726707075883

Bartram, D. (2005). The great eight competencies: A criterion-centric approach to validation. Journal of Applied Psychology, 90(6), 1185-1203, http://dx.doi.org/10.1037/0021-9010.90.6.1185
Beechler, S. \& Woodward, I.C. (2009). The global 'war for talent'. Journal of International Management, 15 (3), 273-285, http:// dx.doi.org/10.1016/j.intman.2009.01.002

Boudreau, J.W., Boswell, W.R. \& Judge, T.A. (2001). Effects of personality on executive career success in the United States and Europe. Journal of Vocational Behavior, 58(1), 53-81, http:// dx.doi.org/10.1006/jvbe.2000.1755

Boyatzis, R.E. (2009). Competencies as a behavioral approach to emotional intelligence. Journal of Management Development, 28(9), 749-770, http://dx.doi.org/10.1108/02621710910987647

Brummett, B.H., Babyak, M.A., Williams, R.B., Barefoot, J.C., Costa, P.T. \& Siegler, I.C. (2006). NEO personality domains and gender predict levels and trends in body mass index over 14 years during midlife. Journal of Research in Personality, 40(3), 222-236, http://dx.doi.org/10.1016/j.jrp.2004.12.002

Bücker, J. \& Poutsma, E. (2010). Global management competencies: A theoretical foundation. Journal of Managerial Psychology, 25(8), 829-844, http://dx.doi.org/10.1108/02683941011089116

Burke, C.S., Sims, D.E., Lazzara, E.H. \& Salas, E. (2007). Trust in leadership: A multi-level review and integration. Leadership Quarterly, 18(6), 606-632, http://dx.doi.org/10.1016/j. leaqua.2007.09.006

Caligiuri, P. (2006). Developing global leaders. Human Resource Management Review, 16(2), 219-228, http://dx.doi. org/10.1016/j.hrmr.2006.03.009

Campion, M.A., Medsker, G.J.\&Higgs, A.C.(1993). Relations between work group characteristics and effectiveness: Implications for designing effective work groups. Personnel Psychology, 46(4), 823-847, http://dx.doi.org/10.1111/j.1744-6570.1993.tb01571.x

Cohen, S.G. \& Bailey, D.E. (1997). What makes teams work: Group effectiveness research from the shop floor to the executive suite. Journal of Management, 23(3), 239-290, http://dx.doi. org/10.1177/014920639702300303

Conger, J.A. (2004). Developing leadership capability: What's inside the black box? Academy of Management Executive, 18(3), 136139, http://dx.doi.org/10.5465/AME.2004.14776188

Cox, T.H., Lobel, S.A. \& McLeod, P. L. (1991). Effects of ethnic group cultural differences on cooperative and competitive behavior on a group task. Academy of Management Journal, 34(4), 827-847, http://dx.doi.org/10.2307/256391

Currie, G. (2007). 'Beyond our imagination': The voice of international students on the MBA. Management Learning, 38(5), 539556, http://dx.doi.org/10.1177/1350507607083206

DiTomaso, N. \& Hooijberg, R. (1996). Diversity and the demands of leadership. Leadership Quarterly, 7(2), 163-187, http://dx.doi. org/10.1016/S1048-9843(96)90039-9

Dulewicz, V. \& Herbert, P. (1999). Predicting advancement to senior management from competencies and personality data: A sevenyear follow-up study. British Journal of Management, 10(1), 13-22, http://dx.doi.org/10.1111/1467-8551.00108

Egan, M. L. \& Bendick Jr., M. (2008). Combining multicultural management and diversity into one course on cultural competence. Academy of Management Learning \& Education, 7(3), 387-393, http://dx.doi.org/10.5465/AMLE.2008.34251675

Ely, R.J. \& Thomas, D.A. (2001). Cultural diversity at work: The effects of diversity perspectives on work group processes and outcomes. Administrative Science Quarterly, 46(2), 229-273, http://dx.doi.org/10.2307/2667087

Ferencikova, S., Mühlbacher, J., Kodydek, G. \& Nettekoven, M. (2012). Role allocation and strategic change: Comparative study of competencies of Austrian and Slovak managers. Ekonomický Časopis, 60, (7), 717-731.

Furnham, A., Petrides, K.V., Tsaousis, I., Pappas, K. \& Garrod, D. (2005). A cross-cultural investigation into the relationships between personality traits and work values. The Journal 
of Psychology, 139(1), 5-32, http://dx.doi.org/10.3200/ JRLP.139.1.5-32

Goldberg, L.R. (1993). The structure of phenotypic personality traits. American Psychologist, 48, (1)26-34, http://dx.doi. org/10.1037/0003-066X.48.1.26

Gonzalez, J.A. (2010). Diversity change in organizations: A systemic, multilevel, and nonlinear process. Journal of Applied Behavioral Science, 46(2), 197-219, http://dx.doi. org/10.1177/0021886310367943

Gosling, S.D., Rentfrow, P.J. \& Swann Jr., W.B. (2003). A very brief measure of the Big-Five personality domains. Journal of Research in Personality, 37(6), 504-528, http://dx.doi. org/10.1016/S0092-6566(03)00046-1

Hackman, J.R., \& Wageman, R. (2005). A theory of team coaching. Academy of Management Review, 30(2), 269-287, http://dx.doi. org/10.5465/AMR.2005.16387885

Hackman, J.R. \& Wageman, R. (2005). When and how team leaders matter. Research in Organizational Behavior, 26, 37-74, http:// dx.doi.org/10.1016/S0191-3085(04)26002-6

Harrison, D.A. \& Klein, K.J. (2007). What's the difference? Diversity constructs as separation, variety, or disparity in organizations. Academy of Management Review, 32(4), 1199-1228, http:// dx.doi.org/10.5465/AMR.2007.26586096

Hartmann, E., Feisel, E. \& Schober, H. (2010). Talent management of western MNCs in China: Balancing global integration and local responsiveness. Journal of World Business, 45(2), 169-178, http://dx.doi.org/10.1016/j.jwb.2009.09.013

Harvey, M. \& Novicevic, M. (2002). The role of political competence in global assignments of expatriate managers. Journal of International Management, 8(4), 389-406, http://dx.doi. org/10.1016/S1075-4253(02)00093-5

Herring, C. (2009). Does diversity pay? Race, gender, and the business case for diversity. American Sociological Review, 74(2), 208-224, http://dx.doi.org/10.1177/000312240907400203

Hogan, J. \& Holland, B. (2003). Using theory to evaluate personality and job-performance relations: A Socioanalytic Perspective. Journal of Applied Psychology, 88(1), 100-112, http://dx.doi. org/10.1037/0021-9010.88.1.100

Hogan, J. \& Ones, D.S. (1997). Conscientiousness and integrity at work. In R. Hogan, J. Johnson \& S. Briggs (Eds.), Handbook of personality psychology, San Diego, CA: Academic Press, 849-870

Homan, A.C., Greer, L.L., Jehn, K.A. \& Koning, L. (2010). Believing shapes seeing: The impact of diversity beliefs on the construal of group composition. Group Processes \& Intergroup Relations, 13(4), 477-493. http://dx.doi.org/10.1177/1368430209350747

Hoon, L.S. \& Lim, V.K.G. (2001). Attitudes towards money and work: Implications for Asian management style following the economic crisis. Journal of Managerial Psychology, 16(2), 159172, http://dx.doi.org/10.1108/02683940110380979

Hopkins, W.E. \& Hopkins, S.A. (2002). Effects of cultural recomposition on group interaction processes. Academy of Management Review, 27(4), 541-553, http://dx.doi.org/10.5465/ AMR.2002.7566059

Horwitz, S.K. (2005). The compositional impact of team diversity on performance: Theoretical considerations. Human Resource Development Review, 4(2), 219-245, http://dx.doi. org/10.1177/1534484305275847

Jehn, K. A., \& Bezrukova, K. (2004). A field study of group diversity, workgroup context, and performance. Journal of Organizational Behavior, 25(6), 703-729, http://dx.doi.org/10.1002/job.257

Jehn, K.A., Northcraft, G.B., \& Neale, M.A. (1999). Why differences make a difference: A field study of diversity, conflict, and performance in workgroups. Administrative Science Quarterly, 44(4), 741-763, http://dx.doi.org/10.2307/2667054
Judge, T.A. \& Bretz Jr., R.D. (1992). Effects of work values on job choice decisions. Journal of Applied Psychology, 77(3), 261271, http://dx.doi.org/10.1037/0021-9010.77.3.261

Kayes, D.C., Kayes, A.B. \& Yamazaki, Y. (2005). Essential competencies for cross-cultural knowledge absorption. Journal of Managerial Psychology, 20(7), http://dx.doi. org/10.1108/02683940510623399

Knight, G. A. \& Cavusgil, S. T. (2004). Innovation, organizational capabilities, and the born-global firm. Journal of International Business Studies, 35(2), 124-141, http://dx.doi.org/10.1057/ palgrave.jibs. 8400071

Knight, D., Pearce, C.L., Smith, K.G., Olian, J.D., Sims, H.P., Smith, K.A. \& Flood, P. (1999). Top management team diversity, group processes, and strategic consensus. Strategic Management Journal, 20(5), 445-465, http://dx.doi.org/10.1002/(SICI)10970266(199905)20:5<445::AID-SMJ27>3.0.CO;2-V

Kolb, A.Y. \& Kolb, D.A. (2005). Learning styles and learning spaces: Enhancing experiential learning in higher education. Academy of Management Learning \& Education, 4(2), 193-212, http:// dx.doi.org/10.5465/AMLE.2005.17268566

Kreiser, P.M., Marino, L.D., Dickson, P., \& Weaver, K.M. (2010). Cultural influences on entrepreneurial orientation: The impact of national culture on risk taking and proactiveness in SMEs. Entrepreneurship Theory and Practice, 34(5), 959-983, http:// dx.doi.org/10.1111/j.1540-6520.2010.00396.x

Kuijpers, M., Meijers, F. \& Gundy, C. (2011). The relationship between learning environment and career competencies of students in vocational education. Journal of Vocational Behavior, 78(1), 21-30, http://dx.doi.org/10.1016/j.jvb.2010.05.005

Matveev, A. V., \& Nelson, P. E. (2004). Cross cultural communication competence and multicultural team performance. Perceptions of American and Russian managers. International Journal of Cross Cultural Management, 4(2), 253-270, http:// dx.doi.org/10.1177/1470595804044752

McAdams, D.P. \& Pals, J.L. (2006). A new Big Five: Fundamental principles of an integrative science of personality. American Psychologist, 61(3),204-217, http://dx.doi.org/10.1037\%2f0003066X.61.3.204

Moberg, D.J. (2006). Best intentions, worst results: Grounding ethics students in the realities of organizational context. Academy of Management Learning \& Education, 5(3), 307-316, http:// dx.doi.org/10.5465/AMLE.2006.22697019

Morgeson, F.P., DeRue, D.S., \& Karam, E.P. (2010). Leadership in Teams: A functional approach to understanding leadership structures and processes. Journal of Management, 36(1), 5-39, http:// dx.doi.org/10.1177/0149206309347376

Mount, M.K., Barrick, M.R., Scullen, S.M. \& Rounds, J. (2005). Higher-order dimensions of the Big Five personality traits and the Big Six vocational interest types. Personnel Psychology, 58(2), 447-478, http://dx.doi.org/10.1111/j.1744-6570.2005.00468.x

Mount, M.K., Barrick, M.R. \& Strauss, J.P. (1994). Validity of observer ratings of the Big Five personality factors. Journal of Applied Psychology, 79(2), 272-280, http://dx.doi.org/10.1037/00219010.79.2.272

Mühlbacher, J. (2007). Kompetenzmanagement als Grundlage strategischer Wettbewerbsvorteile. Vienna: Linde Verlag.

Mühlbacher, J., Kodydek, G., Kovac, J., Putnová, A. \& Novotny, A. (2012). Cultural diversity and competency management in Central Europe. In: M. Rasticova (Ed.), Diversity is reality. Effective leadership of diverse teams in a global environment, Brno: Cerm, 85-100.

Osland, J.S. \& Bird, A. (2000). Beyond sophisticated stereotyping: Cultural sensemaking in context. Academy of Management Executive, 14 (1), 65-79, http://dx.doi.org/10.5465/ AME.2000.2909840 
Pelled, L.H., Eisenhardt, K.M., \& Xin, K.R. (1999). Exploring the black box: An analysis of work group diversity, conflict, and performance. Administrative Science Quarterly, 44(1), 1-28, http://dx.doi.org/10.2307/2667029

Rammstedt, B. \& John, O.P. (2007). Measuring personality in one minute or less: A 10-item short version of the Big Five Inventory in English and German. Journal of Research in Personality, 41(1), 203-212, http://dx.doi.org/10.1016/j.jrp.2006.02.001

Richard, O.C. (2000). Racial diversity, business strategy, and firm performance: A resource-based view. Academy of Management Journal, 43(2), 164-177, http://dx.doi.org/10.2307/1556374

Richard, O.C., Barnett, T., Dwyer, S. \& Chadwick, K. (2004). Cultural diversity in management, firm performance, and the moderating role of entrepreneurial orientation dimensions. Academy of Management Journal, 47(2), 255-266, http://dx.doi. org/10.2307/20159576

Rico, R., Sánchez-Manzanares, M., Gil, F., \& Gibson, C. (2008). Team implicit coordination processes: A team knowledge-based approach. Academy of Management Review, 33(1), 163-184, http://dx.doi.org/10.5465/AMR.2008.27751276

Robertson, I., Gibbons, P., Baron, H., MacIver, R. \& Nyfield, G. (1999). Understanding management performance. British Journal of Management, 10(1), 5-12, http://dx.doi. org/10.1111/1467-8551.00107

Salgado, J.F. (2003). Predicting job performance using FFM and non-FFM personality measures. Journal of Occupational and Organizational Psychology, 76(3), 323-346, http://dx.doi. org/10.1348/096317903769647201

Sánchez, J.C. (2011). University training for entrepreneurial competencies: Its impact on intention of venture creation. International Entrepreneurship and Management Journal, 7(2), 239-254, http://dx.doi.org/10.1007/s11365-010-0156-x

Shachaf, P. (2008). Cultural diversity and information and information technology impacts on global virtual teams: An exploratory study. Information \& Management, 45(2), 131-142, http:// dx.doi.org/10.1016/j.im.2007.12.003

Sippola, A. \& Smale, A. (2007). The global integration of diversity management: A longitudinal case study. International Journal of Human Resource Management, 18(11), 1895-1916, http:// dx.doi.org/10.1080/09585190701638101

Srivastava, S., Guglielmo, S. \& Beer, J.S. (2010). Perceiving others' personalities: Examining the dimensionality, assumed similarity to the self, and stability of perceiver effects. Journal of Personality and Social Psychology, 98(3), http://dx.doi. org/10.1037/a0017057

Stahl, G.K., Mäkelä, K., Zander, L., \& Maznevski, M.L. (2010). A look at the bright side of multicultural team diversity. Scandinavian Journal of Management, 26(4) 439-447, http:// dx.doi.org/10.1016/j.scaman.2010.09.009

Strauss, J.P. \& Connerley, M.L. (2003). Demographics, personality, contact, and universal-diverse orientation: An exploratory examination. Human Resource Management, 42(2), 159-174, http://dx.doi.org/10.1002/hrm.10074
Tyran, K.L. \& Gibson, C.B. (2008). Is what you see, what you get? The relationship among surface- and deep-level heterogeneity characteristics, group efficacy, and team reputation. Group and Organization Management, 33(1), 46-76, http://dx.doi. org/10.1177/1059601106287111

van Knippenberg, D., De Dreu, C.K.W., \& Homan, A.C. (2004). Work group diversity and group performance: An integrative model and research agenda. Journal of Applied Psychology, 89(6), 1008-1022, http://dx.doi.org/10.1037/0021-9010.89.6.1008

Vance, C.M. (2005). The personal quest for building global competence: A taxanomy of self-initiating career path strategies for gaining business experience abroad. Journal of World Business, 40(4), 374-385, http://dx.doi.org/10.1016/j.jwb.2005.08.005

Wageman, R. (2001). How leaders foster self-managing team effectiveness: Design choices versus hands-on coaching. Organization Science, 12(5), 559-577, http://dx.doi.org/10.1287/ orsc.12.5.559.10094

Wageman, R., Hackman, J.R. \& Lehman, E. (2005). Team diagnostic survey: Development of an instrument. Journal of Applied Behavioral Science, 41(4), 373-398, http://dx.doi. org/10.1177/0021886305281984

Warr, P., Bartram, D. \& Brown, A. (2005). Big Five validity: Aggregation method matters. Journal of Occupational and Organizational Psychology, 78(3), 377-386, http://dx.doi. org/10.1348/096317905X53868

Watson, W.E., Kumar, K., \& Michaelsen, L.K. (1993). Cultural diversity's impact on interaction process and performance: Comparing homogeneous and diverse task groups. Academy of Management Journal, 36(3), 590-602, http://dx.doi.org/10.2307/256593

Welch, D.E., Welch, L. \& Piekkari, R. (2005). Speaking in tongues. The importance of language in international management processes. International Studies of Management and Organization, 35(1), 10-27, http://dx.doi.org/10.1007/s11575-008-0019-7

Zaccaro, S.J., Rittman, A.L., \& Marks, M.A. (2001). Team leadership. Leadership Quarterly, 12(4), 451-483, http://dx.doi. org/10.1016/S1048-9843(01)00093-5

Zhou, W. \& Shi, X. (2011). Culture in groups and teams: A review of three decades of research. International Journal of Cross Cultural Management, 11(1), 5-34, http://dx.doi. org/10.1177/1470595811398799

Georg Kodydek is a post-doctoral researcher at the Institute for Change Management and Management Development at the WU Vienna University of Economics and Business. His current research projects focus on Business Ethics, Leadership and Diversity.

Ronald Hochreiter is Assistant Professor at the Institute for Statistics and Mathematics at the WU Vienna University of Economics and Business. His main research areas are Management Science and Risk Management. 